\title{
OHRID'S ANCIENT URBAN ARCHITECTURE BY BORIS ČIPAN AND DUŠAN GRABRIJAN
}

\author{
Serena ACCIAI \\ University of Florence \\ Ph.D. Architect \\ e-mail: serena.acciai@unifi.it
}

\section{ABSTRACT}

The "çardak" is the core room of any Macedonian house, similar to the living room for Le Corbusier. Based on the work of Dušan Grabrijan on the Macedonian house type and on the work of Boris Čipan on the Ohrid's housing architecture, the current study explores the peculiarity of the so-called Ohrid's ancient urban architecture. By carrying out an analysis of the above-mentioned studies, this paper analyzes the origins, the differences, the program, the location, the cultural context, the organization, the built-in furniture, the technological construction, the anthropological expressions, and the main architectural elements of Ohrid's houses.

This written provides a new look at Ohrid's ancient urban architecture, by trying to linking the most important studies led by modern architects on this topic. Studies that revealed the fundamental aspect of this house type: its intrinsic modernity.

Keywords: sofa house - çardak - modernity - human scale.

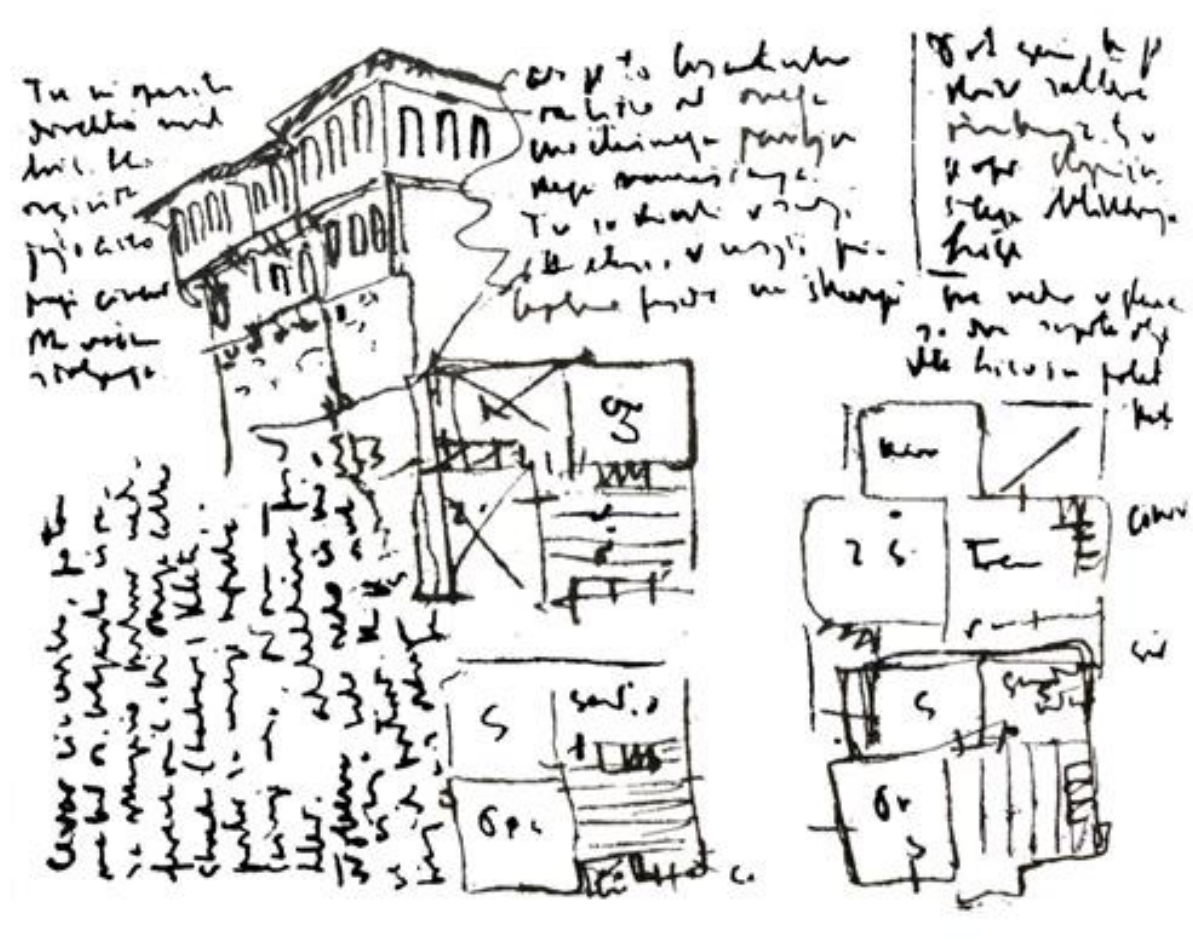

Figure 1: Dušan Grabrijan's sketches on the Macedonian house. 


\section{BODY OF THE TEXT}

The term Rumelia means "Land of the Roman" in Turkish and refers to the lands conquered by the Ottoman Turks from the Byzantine Empire: in time, the expression came to signify the Balkan provinces of the empire, but after 1885 it ceased to indicate any political division. However, a shared tradition of vernacular housing - the so-called sofa house - continued to exist as an important element of the architectural culture of this region. Since the 1930's, in the new nation-states emerging in old Rumelia from the collapse of the Ottoman Empire, a group of architects: Dimitri Pikionis, Paul Smarandescu, Henrietta Delavrancea, Sedad Hakki Eldem, Dušan Grabrijan, Aleksandar Deroko, Branislav Kojić, and later Boris Čipan, have promoted the study of civil architecture as a fundamental source for the development of their modern architecture making treasure of the housing tradition of this ancient land. These architects created a sort of network ${ }^{1}$ among themselves and had a relevant role in the formation of cultural awareness of traditional housing heritage in their own countries. This vernacular house type created a strong connection and common interest in the architecture in today's Greece, Romania, Turkey, Bosnia, Serbia, and Macedonia. In the Balkan peninsula, national identities were based, also, on the idea of a "national home". However, architects from different countries in this area were inspired by the same type of house-the sofa house.

The well-known Turkish architect Sedad Hakkı Eldem (1908-1988) is the author of the most comprehensive typological study on the traditional the sofa house. In his work entitled Turk Evi Plan Tipleri $^{2}$ (1954), Eldem clearly identified the constitutive elements of the Turkish house type ${ }^{3}$ spread throughout the ancient territories of Rumelia and Anatolia. My research begins by examining Eldem's observations-that throughout the 500 years of its existence, the sofa house has undergone many developments while, at the same time, maintaining its characteristic elements. The plan of the house is the most important of these elements. Eldem observed that:

"The Turkish house is the type of house found within the boundaries of the Old Ottoman Empire, in the territories formerly called Rumelia and Anatolia. It is a striking fact that houses which are hundreds of miles distant from each other, which have been built under greatly differing conditions, have a plan which in its main lines, is the same for all"

Furthermore, Eldem identified three fundamental elements of this house type. These were:

- The rooms;

- The hall (sofa in Turkish) and their adjoining rooms;

- The stairs.

According to Eldem, the sofa represented the house itself. He considered this hall the most distinctive of the three compositional elements, and he defined typology based on the role of the sofa in the house plan. Although he recognized that this type of house was present in a vast geographical area, he continued to refer to it as a "Turkish house". Over time many scholars defined the same house type with various, different names, referring to the regions or ethnic groups of the inhabitants. Thus, this house type has been called "(Northern) Greek house," "Bulgarian (National) Revival house," and "Macedonian traditional house" (Marinov, 2017). Another renowned Turkish architect,

1 See Acciai, S. (2017). The Ottoman-Turkish House according to Sedad Hakki Eldem, A refined domestic culture suspended between Europe and Asia', ABE Journal [Online], No. 11, 1-32.

2 Eldem, S. H. (1954) Türk Evi Plan Tipleri, Istanbul Teknik Univesity, Istanbul.

3 Typological derives from the word type (or túmoৎ in Greek), which means " imprint, character, figure, model". 
Dogan Kuban 4 employed a typological concept, speaking of this housing tradition as "the hayat house" (Erarslan 2019).

Dušan Grabrijan and Juraj Neidhardt토 described the presence of the "divanhane" (receiving room) as a "proto-modernist" feature of the traditional house. Again Grabrijan, noticed how the "çardak" (wooden veranda) was the core room of any "Macedonian house ${ }^{6 "}$. The "çardak" is yet another variation of the essential sofa space.

Dimitri Pikionis, a well-known modern Greek architect, referring to the houses of Kastoria, Kozani, Siatisia (villages of former Rumelia), defined this housing tradition as the "art of the Greek people."

Branislav Kojić8 named the local traditional house type "Balkan profane architecture" while Aleksandar Deroko, another leading Serbian architect, used the term "urban house of Oriental type".

Boris Čipan preferred to not give a national definition to the houses in Orhid, Macedonia. He referred to the architecture of his city as "our ancient urban architecture"10.

Among the eastern modern architects mentioned above, Eldem was the most devoted in the study of the sofa house type. Furthermore, from Eldem's correspondence11, we see that he was working on the Turkish house also outside of Turkey. In fact, he was interested in the traditional architecture of countries that had experienced Ottoman domination, which he studied through the publications of other intellectuals and architects, such as Deroko, Moutsopoulos, Grabrijan, and Kojić. In this regard, Sedad Eldem's papers and studies will be main sources of my quest. The study of how Eastern modern Mediterranean architects, since the 1930s, made full use of the vernacular housing typology in the reinterpretation of the tradition toward a modern context, deserves scholarly attention.

In the most general season of studies that Modern architects took up since the 1930s, in Macedonia stand up Dušan Grabrijan and Boris Čipan's work on the vernacular house type. Particularly, they considered Ohrid's ancient urban architecture as an incunabulum of Macedonian way of build and, at the same time, as a modern way of life.

Dušan Grabrijan (1899-1952) was a Slovenian-Bosnian architect architectural theorist and professor. He belonged to that group of Plecnik's students ${ }^{12}$ who come to Paris in order to attend the advanced study courses offered at École des Beaux-Arts. During the 1930s, he worked as a professor at Secondary Technical School in Sarajevo, where, during the 1930s, he authored several publi-

4 Kuban, D. (1995), The Hayat house, Muhittin Salih EREN, Istanbul.

5 Grabrijan, D., Neidhardt, J. (1957), Arhitekture Bosne i put u suvremeno. Architecture of Bosnia and the way [towards] modernity, Državna založba Slovenije, Ljubljana.

6 Grabrijan, D. (1955), Makedonska kukja, Državna založba Slovenije, Ljubljana.

7 Pikionis, D., Designs from houses in Zagora, 1939 - from Dimitri Pikionis' papers at Benaki Museum.

8 Kojić, B. (1949), Old Urban and Village Architecture in Serbia, Prosveta, Beograd,

9 Deroko, A. (1961), "Deux genres d'architecture dans un monastère," Revue d'études byzantines, vol. 19, 382-389. URL: http://www.persee.fr/doc/rebyz_0766-5598_1961_num_19_1_1271.

10 Čipan, B. (1963-1964), L'ancienne architecture d'immeuble à Ohrid, in Actes du XIle Congrès international d'études byzantines: Ochride 10-16 septembre 1961, Comité yougoslave d'études byzantines, Beograd, 149-162.

11 Acciai, S. (2017), The Ottoman-Turkish House according to Sedad Hakki Eldem, A refined domestic culture suspended between Europe and Asia, cit.

12 See Bogo, Z. (2017), Plečnikovi študenti in drugi jugoslovanski arhitekti v Le Corbusierovem ateljeju (Plečnik's students and other Yugoslav architects in Le Corbusier's studio), MAO KUD Polis, Ljubljana, 
cations on a variety of topics, including the Oriental House ${ }^{13}$, adapted to the demands of Bosnian culture.

Regarding the Macedonian housing vernacular heritage, the fundamental Grabrijan's contribution is the book Makedonska kukja ${ }^{14}$, where the author with his student studied the architecture of Macedonia. They choose the more prosperous region: from Skopje along the Vardar Valley, from towards the east to Kratovo, Kočane, Štip, and Strumica, and from Skopje towards the west to Ohrid, Struga, over St. Jovan Bigorski to Tetovo.

Boris Čipan (1918-2012) was a Macedonian architect. He was a prominent figure of Macedonian modern architecture after the Second World War. He also tried to define the nature of ancient housing architecture of the Balkan regions: in fact, in his relevant paper entitled L'ancienne architecture d'immeuble à Ohrid Čipan ${ }^{15}$ arguments how the Ottomans have clearly adopted the (Byzantine) housing tradition and continuing to modify it following their needs. He came from Ohrid and he used to say: "I had two privileges in my life-being born in Ohrid and becoming an architect"16. It is evident, looking at his long career, that Ohrid's architecture had on Čipan an essential role in shaping its formation as an architect. He had a sort of love with the ancient Ohrid's buildings, and particularly with St. Sopia (Byzantine church) where he had the opportunity to work for a long time. Furthermore, he authored a fundamental book on the peculiarity of Ohrid's architecture ${ }^{17}$.

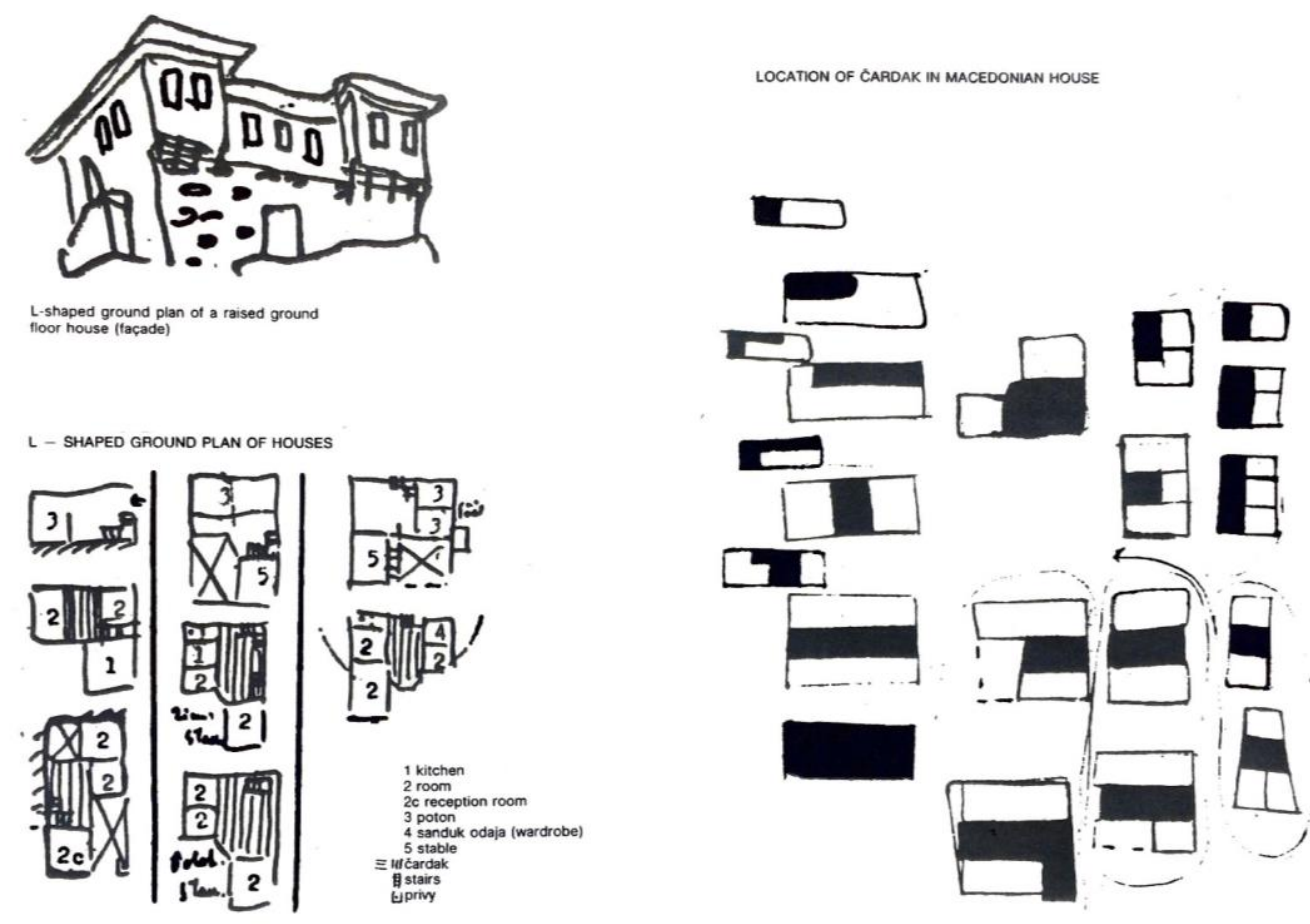

Figure 2: Dušan Grabrijan's sketches. Location of the çardak in the Macedonian house.

13 Grabrijan, D. (1984), The Bosnian Oriental architecture in Sarajevo, Dopisna Delavska Univerza, Ljubljana,

14 Grabrijan, D. (1955), Makedonska kukja, cit.

15 Čipan, B. (1963-1964) L'ancienne architecture d'immeuble à Ohrid, cit.

16 AA.VV, (2017). Boris Čipan, Following the tracks of a modernist, Skopje, Museum of the city of Skopje,

17 Čipan, B. (1983), The old city architecture in Ohrid, Makedonska kniga, Skopje. 
Due to the climate, the Macedonian house has a winter dwelling in the massive ground floor which is constructed of stone and also includes the cellar and a summer dwelling in the upper floor, which is of a wooden framework construction. In winter the portable cooking stove put into the winter room which thus serves as both kitchen and living room. The summer dwelling is organized around a çardak (i.e. upper sofa porch, which gives autonomy to the other rooms). The çardak may be open at one side and extended into a tronj (open terrace). In hot summer, this is the living room and also serves as a sleeping quarter. In mountainous regions the çardak is glassed-in. In the Macedonian house, everything is organized around the çardak: Therefore obscure rooms are exposed to light and air. Although the furniture is absent this fascinating type of room seems extremely rich. There are niches at the entrances of the other rooms; the wight of the çardak's walls vary and the stairs are located in an open space. The attic is usually open.

Grabrijan analyzed the various position of the çardak (living room) in the Macedonian house plan. With his students he identified that this irreplaceable compositional element could be placed:

- in the front of the house;

- in the corner and in the side of a high house;

- in the center;

- in the middle of a low house;

- in the corner of raised floor house-facade;

- $\quad$ in the middle of $L$ shaped house;

The Ohrid's houses are characterized by two different types:

- $\quad$ high houses usually for Muslim inhabitant;

- low houses usually for Christian inhabitant;

The ancient Ohrid lies on the saddle-shaped hill that rises 100 meters above the plain, the northern half of which is formed by the fertile plain and the southernmost half by the limpid lake. From the medieval point of view, the city lies in a remarkable strategic position. As the capital of the first Macedonian state of Tsar Samulio (X-XI century), the city had a great fortress that still exists nowadays. Around that monumental urban structure, on the east and south slopes of the hill are the sculptural houses of the inhabitants of Ohrid. The other conditions for the development of a noble architecture are also extraordinary. The beautiful view of the lake, which ends with the elegant silhouette of the mountains, coincides with maximum sunshine. Thanks to the warm lake, the climate is remarkably pleasant and a fitting mix of Mediterranean and mountain climate. Thus, the whole town represents a unique organic type of settlement. The main points of the city are marked by the monumental buildings of Middle Ages.

Both Grabrijan and Čipan highlighted how Ohrid's ancient urban architecture had a special relationship with its building site: the houses of Ohrid seem to grow like a sculpture out an amorphous natural environment; over the narrow streets and roofs, çardaks seek broad views of surroundings.

Ohrid owes its particular character to the historical division of the area with the Christian on the hill and the Muslim on the plain. The business district, also in the town center lies exactly where the two parts meet. The architecture was bound to reflect the level of such a cultural city. 
The eastern modernist architects mentioned at the beginning of this paper (Eldem, Delavrancea, Pikionis ${ }^{18,}$ Grabrijan, Kojić, Čipan) considered the house type of former Rumelia as a way of life very close to the modern idea of living. They saw modern features in these houses ${ }^{19}$, such as free plan, ample windows, lightness, sensitivity to the site, priority to the comfort over functionalist aspects, relationship with nature.

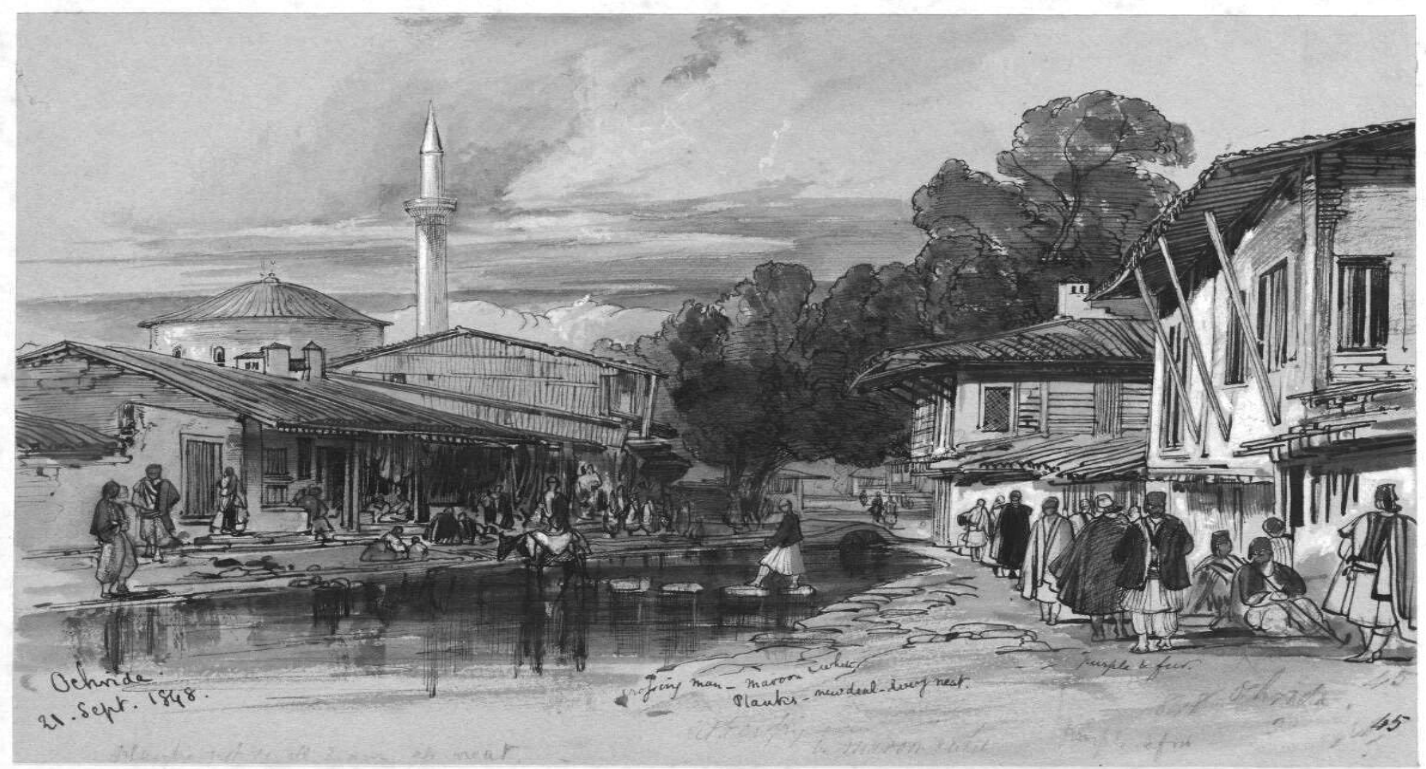

Figure 3: Edward Lear's view of Ohrid.

Particularly, Grabrijan and Čipan found similarities between the Macedonian and the modern house. They referred to the up-to-date relationship between the ground plan and the elevation, to the independence of the inner disposition of room from the wall structure, to the architecture of the outer rooms, to the plastic modeling of the house above its supporting walls, to the harmony of architecture with nature, to the desire for a view and, to the built-in furniture.

\section{CONCLUSION}

To summarize, based on the studies Grabrijan and Čipan, it is recognizable that one of the basic messages of the old Macedonian town is its unbroken link with tradition.

Boris Čipan, who was very committed in the development of the Modern Macedonian architecture, employed the Macedonian house type concept in some of his projects. That, it is evident in the project for a villa in Belgrade (1939-40) where the corner of the house is a modern version of the çardak.

18 For a comparative study of the views shared by Pikionis and Eldem: E. Bastéa, (2003) "Dimitris Pikionis and Sedad Eldem: Parallel Reflections of Vernacular and National Architecture," in The Usable Past: Greek Metahistories, eds. Keith Brown and Yannis Hamilakis (Lanham, MD; Boulder; Lexington Books, New York; and Oxford,147-169.

19 Only Le Corbusier, among the CIAM architects, recognized the modernity of the Ottoman/Balkan house type: see Udovički-Selb, D.F. (2013), Les Balkans, genèse des « Cinq points de l'architecture » in L'invention d'un architecte, Le voyage en Orient de Le Corbusier, Fondation Le Corbusier, Edition de la Villette, Paris. 
For Čipan "the old" was always an inspiration for "the new". Another message coming from Ohrid's ancient urban architecture is the organic connection of buildings with the natural environment. The more fascinating element of the Macedonian house type is undoubtedly its human scale.

In the Balkans, housing heritage was employed by eastern modern Mediterranean architects to give to modern architecture a vernacular character.
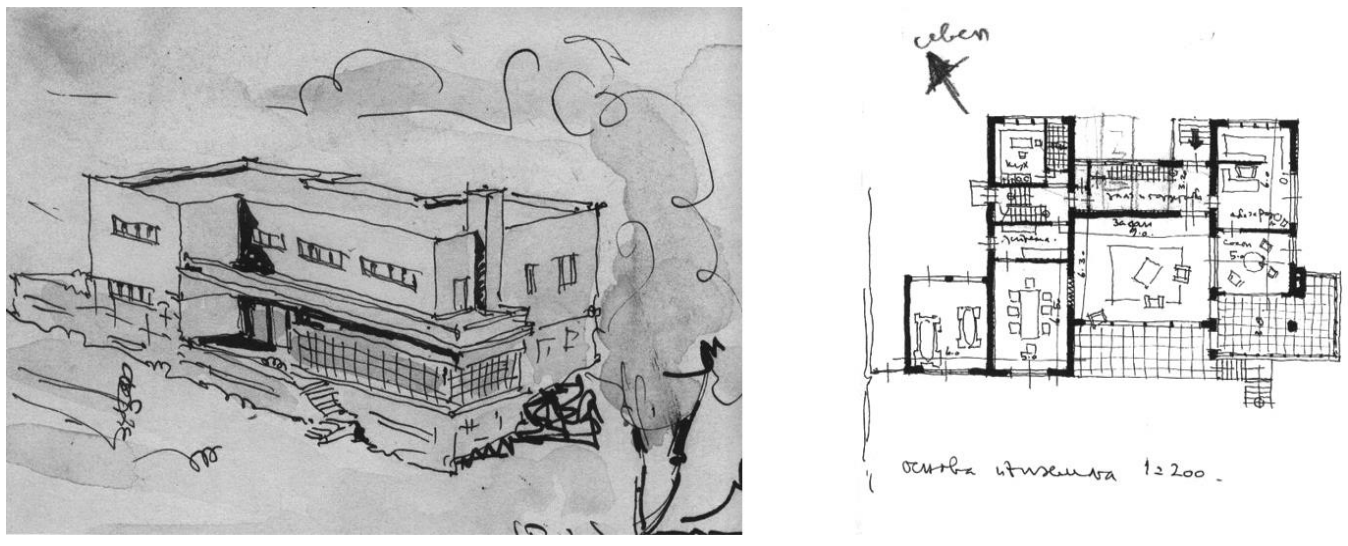

Figure 4: Boris Čipan, project of a villa in Belgrade (1939-40).

\section{ACKNOWLEDGEMENTS}

A special thanks to Marija Ljakoska for her irreplaceable assistance in familiarizing me with Boris Čipan's work.

\section{REFERENCES}

Acciai, S. (2016), Divanhane, the receiving room, Firenze Architettura, (2, 2016), 146-151.

Acciai, S. (2017), The Ottoman-Turkish House according to Sedad Hakki Eldem, A refined domestic culture suspended between Europe and Asia', ABE Journal [Online], No. 11, 1-32.

Acciai, S. (2018), Sedad Hakkı Eldem, an Aristocratic Architect and More, FUP Firenze University Press, Firenze.

Acciai, S. (2018), The Transnational Nature of Balkan Houses: an Ethnographic Analysis. In Jovana Brankov, Marija Drobnjaković (eds.), Belgrade\&Loznica: proceedings of the International Conference The Balkan Peninsula of Jovan Cvijić: Historical Background in Human Geography, 233-242.

Bastéa, E. (2003), Dimitris Pikionis and Sedad Eldem: Parallel Reflections of Vernacular and National Architecture". In The Usable Past: Greek Metahistories, eds. Keith Brown and Yannis Hamilakis, Lanham MD Boulder, Lexington Books, New York; and Oxford,147-169.

Cerasi, M. (1986), La città del Levante, Editoriale, Jaca Book, Milano.

Čipan. B. (1963-1964), L'ancienne architecture d'immeuble à Ohrid", Actes du Xlle Congrès international d'études byzantines: Ochride 10-16 septembre 1961, Beograd, Comité yougoslave d'études byzantines, 149-162.

Čipan, B. (1983), The old city architecture in Ohrid, Makedonska kniga, Skopje, (first edition 1955).

Cvijić J. (1906), Les éléments de la géographie et de la géologie de la Macédoine et de l'ancienne Serbie. Académie des Sciences de Belgrade, Belgrade.

Cvijić J. (1918), La péninsule balkanique : géographie humaine, Armand Colin, Paris.

Grabrijan, D. (1955), Makedonska kukja, Državna založba Slovenije Ljubljana. 
Grabrijan, D., Neidhardt, J. (1957). Arhitekture Bosne i put u suvremeno. Architecture of Bosnia and the way [towards] modernity, Državna založba Slovenije, Ljubljana,

Eldem, S. H. (1954), Türk Evi Plan Tipleri, Istanbul Teknik University, Istanbul.

Erarslan, A. (2019), An Evaluation on the Turkish House with Exterior Sofa, Pro Ligno, Vol. 15, No 117 33.

Marinov, T. (2017), "The "Balkan House": Interpretations and Symbolic Appropriations of the Ottoman-Era Vernacular Architecture in the Balkans". In Entangled Histories of the Balkans. Leiden, The Netherlands, BRILL.

Mazower, M. (2000), The Balkans, Weidenfeld \& Nicolson,London.

Megas, G. A. (1951), The Greek house: its evolution and its relation to the houses of the other Balkan peoples. Athens, Greece, Ministry of Reconstruction.

Rheidt K. (1990), Byzantinische Wohnhäuser des 11. bis 14. Jahrhunderts in Pergamon. Dumbarton Oaks papers, Dumbarton Oaks Center for Byzantine Studies,Washington DC, 44. 195-204.

Udovički-Selb, D. F. (2013), Les Balkans, genèse des " Cinq points de l'architecture ». In AA.VV. (eds.), L'invention d'un architecte, Le voyage en Orient de Le Corbusier, Fondation Le Corbusier, Edition de la Villette, Paris, 210-217.

AA.VV, (2017), Boris Čipan, Following the tracks of a modernist, Museum of the city of Skopje, Skopje. 